\title{
Research on the Digital Maturity of Mechanical Engineering Companies in Russia
}

\author{
Pavel E.V. \\ St. Petersburg State University, \\ Saint Petersburg, Russia, \\ e.pavel@spbu.ru
}

\author{
Kudryashova T.V. \\ Yaroslav-the-Wise Novgorod State University, \\ Veliky Novgorod, Russia, \\ tatyana.kudryashova@novsu.ru
}

\author{
Bykova P.A. \\ St. Petersburg State University, \\ Saint Petersburg, Russia, \\ polinaabykovaa@gmail.com
}

\begin{abstract}
The article examines the process of digital transformation of machine-building companies in Russia. A brief overview of digital transformation studies conducted in Russia is presented. It is concluded that these studies are still of an overview and informational nature; the conducted studies lack a methodology for measuring the achieved digital maturity. The approaches to the studies of digital maturity carried out by foreign researchers are considered. It is noted that the use of foreign developments in Russia has limitations associated with the lack of necessary statistical information and the specific features of the organization of mechanical engineering. The authors revealed the relationship between marketing processes, total quality management and digitalization. A methodology for calculating the digital maturity index of a company has been developed, taking into account the specifics of the industry under study and the characteristics of the Russian economy. A quantitative assessment of the digital maturity of a number of engineering companies has been carried outfit is concluded that most companies in the industry have low to moderate digital maturity.
\end{abstract}

Keywords-digital transformation, digital maturity index, engineering industry, machine-building companies.

\section{INTRODUCTION}

In the context of digital transformation, companies face new challenges, since almost all sectors of the economy are entering a new level of interaction. The researchers note that "Digital transformation is a large-scale adaptation of business to the new conditions of the digital economy and one of the main elements of the new management paradigm of the $21 \mathrm{st}$ century" [1]. Digitalization allows companies to improve the quality of relationships with partners and customers, optimize operational activities, expand the range of tools for marketing activities, etc.It gives the company / business new competitive advantages and therefore is valuable to it. This approach is consistent with a value-based management concept. It is getting very important to understand how quickly the digital transformation process is developing, whether it is going well and whether it brings useful benefits to the company / business. In these conditions, the level of "digital maturity" of a company / business becomes a quality criterion for the developing process of digital transformation.

An increasing number of proposals for improving the business models of various economic entities are associated with the use of big data, which is noted, in particular, in the study by Alina Sorescu [2]. The use of modern information technologies is even more important for the development of business structures[3, 4].

At the same time, digital transformation affects both small and medium-sized businesses [5], as well as large companies in various sectors of the economy [6].

The research on digital maturity of companies is actively carried out in different countries. Economists have moved from survey studies of digitalization to developing specific methodologies, models and metrics. For example, the companies Gartner, Deloitte, Massachusetts Institute of Technology (MIT), the consulting company Altimeter-Prophet and others conducted research in this area and developed their own approaches to this issue $[1,7]$.

The study of the digital transformation of the economy in Russia has a rather short history. The earliest research began about three years ago. In 2018, a study of the adaptability of the country's high-tech complex to the digital economy was conducted in Russia [8]. This study covered more than 300 organizations of the high-tech complex in Russia, and more 
than 500experts took part in it. The Society for Systemic Economic Analytics of the Defense Industry Complex prepared a report on its results. It was based on the analysis of the opinions of specialists collected as a result of surveys, questionnaires, working groups and brainstorming sessions. It was concluded that the surveyed companies revealed "a fairly low level of adaptability due to the low level of maturity of digital competencies among key employees and the consideration of individual elements of digital transformation in the practice of strategic management of organizations".

In the same year, a study "Digital transformation in Russia" was conducted [9]. .It covered 15 industries and more than 300 Russian companies. All companies studied were divided into four groups: beginners, laggards, catch-up, and leaders. Leaders are characterized by a widespread digital culture and project management practices in the company. According to Russian researchers, the most important areas of digital transformation for companies are the following: customer focus, collaboration, data, innovation, value, people. A study conducted by the same group of scientists in 2020 showed that already twice as many companies began to approach this issue systematically. The starting point was the development of a digital transformation strategy [10].

A KPMG study conducted in Russia in 2019 [11] covered more than 100 companies in key sectors of the Russian economy. It was again conducted in the form of a survey and made it possible to draw the following conclusions: the digital transformation of Russian companies has begun, but it is not systemic in nature, mainly individual projects and activities are being carried out; there are several technologies that are being more actively implemented by Russian companies robotization, chat bots, big data analysis and machine learning; increasing labor productivity and reducing costs are the main goals of digitalization projects; more than half of Russian companies do not yet seethe need to introduce the position of the head of the digitalization program; Russian companies lack the maturity of business processes and competencies to carry out extensive digitalization.

The studies conducted in Russia are of an overview nature and do not reflect the industry specificity of digitalization processes.

\section{RESULTS AND DISCUSSION}

Recently, there has been a growing interest in a more detailed study of the course of digital transformation in companies and in determining the degree of their digital maturity.

Researchers of the world's leading economies have already begun developing tools to measure and manage digitalization. The MIT Center for Digital Business and Capgemini Consulting divide companies into four groups according to their digital maturity [12]: beginners, conservatives, fashionistas and digirati.By digital intensity, on the one hand, and by the intensity of transformation management, on the other, companies are divided as follows: at the lower level are beginners and conservatives, and at a higher level are fashionistas and digirati.Digital Beginners make very limited use of the digital opportunities available. At the same time, they can be mature companies and operate using ERP technologies or successfully engage in e-commerce. They share their bottom positions with Digital Conservatives. They prefer prudence over innovation and are skeptical of new digital trends. Although these companies tend to spend wisely, their caution may cause them to miss out on valuable opportunities that their competitors will take advantage of. More digitally advanced companies are Digital Fashionistas. These companies have implemented or experimented with many attractive digital applications. Not all of these initiatives have proven capable of creating value. Digital Fashionistas are interested in digital transformation, but their digital transformation strategy is not based on real knowledge of how to maximize its business benefits. The most advanced firms areDigirati, in other words, the cyber elite. They understand how to add value through digital transformation. They combine a transformative vision, thorough management, and participation with ample investment in new opportunities. Through vision and engagement, they develop a digital culture that can help them to anticipate future changes and implement them reasonably. By investing and carefully coordinating digital initiatives, they continually enhance their digital competitive advantage.

The proposed classification reflects the different degrees of digital maturity of companies, but does not allow quantifying it.

Deloitte has developed a universal digital maturity model DMM (Digital Maturity Model), which assesses digital capabilities in five perspectives: Customer, Strategy, Technology, Operations, and Organization\& Culture. [13]. Deloitte believes that the content of the digital maturity model is constant, but the level to which an organization should be mature in eacharea depends on a particular company's business strategy, business model and operating model.

The Deloitte Model shows the structure of digital maturity well, but does not quantify it.

The analytical agency Arthur D. Little has developed the Digital Transformation Index [14], according to which companies can be divided by the degree of digital transformation into those characterized as "Digital aware", "Digital adaptive", "Digital oriented" and "Digital centric". This study focused on leading companies in all sectors of theeconomy. It was noted that, on average, all industries are only "adapting to digital technologies".

In our opinion, the use of indices and models developed by foreign companies can only be partially implemented in Russia. The use of these indices by Russian companies will not provide a reliable assessment. This is due, first of all, to the fact that there are a number of features [15] that are characteristic of the Russian engineering industry (in the organization, in the structure, in the technologies used, in scale, in the availability of financial resources). The complexity of the calculation is also a limiting factor. Therefore, it is necessary to develop an easy-to-use digital maturity index (DMI) for engineering companies operating in Russia.

\section{RESEARCH QUESTIONS}

What processes in the company have already undergone digitalization to one degree or another?

What digital tools / technologies should be used in the first place when conducting digital transformation? 
How to measure the current level of transformation of the company's traditional business processes into digital business processes? Is it possible to quantify it (develop a DMI)?

The aim of the study is to develop a methodology for calculating the digital maturity index for the mechanical engineering companies in Russia that would be convenient in calculation.

\section{RESEARCH METHODS}

Russian statistics are not yet able to track various aspects of digitalization and applied technological solutions that form the basis of digital transformation in various industries [16]. The authors analyzed digital tools used in companies using available information sources. In engineering companies that produce products for the consumer market, digital transformation primarily affects marketing and product quality assurance processes.

Figure 1 (Fig. 1) shows the relationship between product marketing parameters (4P concept), the digitalization process and total quality management (TQM). It lies in the fact that the required quality of the product can be fully ensured only when all the needs for its properties are identified. Digital tools used to obtain marketing information on the degree of customer satisfaction with product quality and to improve the quality of products are beginning to be used by Russian companies in the transition to digital transformation in the first place.

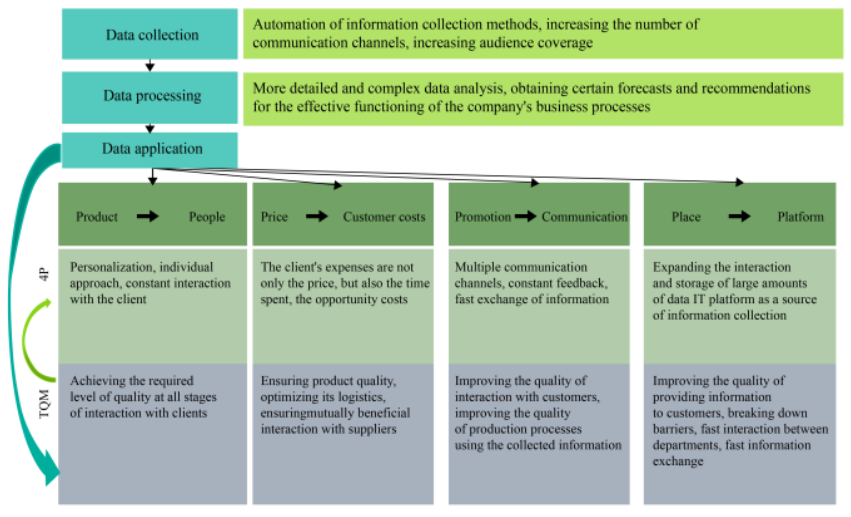

Fig. 1. The relationship of marketing and TQM within digitalization processes

With the help of the involved experts, the presence / absence of certain digital tools in the company and their use were analyzed. It has been established that digital tools used at enterprises can be grouped in three areas:1.Digital technologies in manufacturing (Big data; lean manufacturing; digital manufacturing; machine learning); 2.Digital marketing tools (integration of a CRM system into an ERP system; corporate website; traffic analytics tool; online chat on the site; use of social networks; You Tube as a promotion channel; virtual tours of the plant); 3.Development of the basic components of the company's digital infrastructure (digital training of personnel; maintaining digital infrastructure; social media marketing; advertising on websites, search engines; the position of a digital marketing specialist in the company).

The experts rated each metric from 1 to 5 and calculated the weight of each metric. On the basis of empirical data obtained from open data of companies, the digital maturity indices of the companies under study were calculated. The assessment of the calculated indices and the assessment of the level of digital maturity of the company was carried out according to the following scale:

0-0.3: Low level of digital development. The company uses digital tools only in one of the areas of operation, or does not use them at all.

0.3-0.7: Average level of digital development. The company partially uses production and marketing digital tools. It is possible to use some items of expenditure to maintain their functioning.

0.7-1: High level of digital development. The company applies digital tools in both production processes and marketing. The company allocates items of expenditure to maintain their functioning.

The conclusion about the degree of digital maturity is made depending on the range of values in which the calculated index falls. This algorithm for calculating the digital maturity index, according to the authors, takes into account industry specifics and is easily calculated in company conditions.

\section{FINDINGS}

A company's digital maturity index is a comprehensive metric that measures its digital maturity level. It reflects the degree of integration of digital technologies / tools into the company's activities.

The basis for the study of the digital maturity of companies using the proposed approach was a group of companies operating in Russia in the engineering industry, specializing in the production of household appliances for the consumer market. The sample included JSC KZH Biryusa [17, 18], CJSC Stinol [19], LLC LG Electronics RUS [20, 21], LLC BSH Bytovye Pribory [BSH Household Appliances] [22] and CJSC Indesit International [23, 24], "Plant named after Sergo" (POZIS), Plant of Household Refrigerators "DON" [25]. These companies are present on the Russian market and manufacture products. The following manufacturers of household appliances were also considered: Orsk Refrigerator Plant LLC, Velikoluksk Household Appliances Plant (VZBT), Smolensk Refrigerator Plant, SEPO-ZEM - Saratov. However, it turned out that these companies, which successfully operated in the market at the beginning of the first decade of the third millennium, could not withstand the competition and closed, declared themselves bankrupt or ceased production in 2020.We did not consider them further.

After processing empirical information obtained from the websites of these companies and from the reporting forms, the following index values were determined (Table I).

The results obtained indicate that at the time of calculation, digital transformation in the considered companies in the industry is at a low or medium level.

However, the proposed approach makes it possible to identify the existing problems and resolve them. If a company develops a digitalization strategy, invests in the development of missing digital tools, and transfers more and more processes to digital technologies, it can move to a higher cohort in a relatively short time. If the company's management does not make efforts and allocate financial resources to maintain digitalization, then the company can slide to the lower level and lose in the competition. 
TABLE I. INDEXES OF DIGITAL MATURITY OF COMPANIES IN THE INDUSTRY

\begin{tabular}{|c|c|c|}
\hline \multicolumn{3}{|c|}{ Index scale } \\
\hline $\mathbf{0 - 0 , 3}$ & $\mathbf{0 , 3 1 - 0 , 7}$ & $\mathbf{0 , 7 1 - 1 , 0}$ \\
\hline $\begin{array}{c}\text { LLC "rsk Refrigerator } \\
\text { Plant"-0,0825 }\end{array}$ & $\begin{array}{c}\text { JSC KZH "Biryusa"- } \\
0,42\end{array}$ & - \\
\hline $\begin{array}{c}\text { JSC "Stinol", } \\
\text { refrigerator plant - } \\
\text { 0,2211 }\end{array}$ & $\begin{array}{c}\text { LLC "LG Electronics } \\
\text { RUS"-0,51 }\end{array}$ & - \\
\hline $\begin{array}{c}\text { Household Refrigerator } \\
\text { Plant "DON"-0,231 }\end{array}$ & $\begin{array}{c}\text { "Plant named after } \\
\text { Sergo" (POZIS) -0,52 }\end{array}$ & - \\
\hline & $\begin{array}{c}\text { LLC "SH Household } \\
\text { Appliances"-0,56 }\end{array}$ & - \\
\hline & $\begin{array}{c}\text { CJSC "Indesit } \\
\text { International"-0,57 }\end{array}$ & - \\
\hline
\end{tabular}

a. Source: compiled by the authors

To monitor the progress of the digitalization process, a company must calculate this index at least once a year. The importance of using the index for the economy of the enterprise lies in the fact that it helps to assess the state of the company's digital transformation; determine the level of digital maturity of the company; identify missing parameters of digital transformation.

\section{CONCLUSION}

- The digital transformation of companies in Russia is gradually taking place, their digital maturity is growing.

- Key areas for assessing digital maturity are: digital culture and competencies; the level of digitalization of business processes; data-driven management; digital infrastructure; customer experience and marketing management; product and service value management; R\&D and innovation, but so far it has not been possible to cover everything and include in the index due to problems with the necessary statistics.

- The proposed digital maturity index allows assessing digital transformation at the initial stage in three areas: digital technologies in production; digital marketing tools; development of the basic components of the company's digital infrastructure.

- The proposed index can be used to regularly track changes in the digital maturity of a company. It will allow the company's management to independently determine the level of digital maturity of the company's business processes in terms of marketing and TQM, identify existing shortcomings and determine the directions for further digital transformation.

- Currently, the level of digital maturity of mechanical engineering companies in Russia is at a low or medium level.

\section{References}

[1] D.V. Kuzin, "Problems of digital maturity in modern business" [Problemy cifrovoj zrelosti v sovremennom biznese], The world of new economy, 2019, vol. 13(3), pp. 89-99. (In Russ.).

[2] A. Sorescu, "Data Driven Business Model Innovation", Journal of Product Innovation Management, 2017, vol. 34(5), pp. 691-696. DOI: https://doi.org/10.1111/jpim.12398

[3] P. Setia, and P.C. Patel, "How information systems help create OM capabilities:Consequents and antecedents of operational absorptive capacity", Journal of Operations Management, 2013, vol. 31(6), pp. 409431. DOI: https://doi.org/10.1016/j.jom.2013.07.013
[4] T.J.V.Saldanha, N.P. Melville, R. Ramirez, and V.J. Richardson, "Information systems for collaborating versus transacting:Impact on manufacturing plant performance in the presence of demand volatility", Journal of Operations Management, 2013, vol. 31(6), pp. 313-329. DOI: https://doi.org/10.1016/j.jom.2013.07.007

[5] M. Ghobakhloo, and N.T. Chingc, "Adoption of digital technologies of smart manufacturing in SMEs", Journal of Industrial Information $\begin{array}{llll}\text { Integration, } & 2019, & \text { vol. } & 16 .\end{array}$ https://doi.org/10.1016/J.JII.2019.100107

[6] P. Lara, M. Sánchez, and J. Villalobos, "Enterprise modeling and operational technologies (OT) application in the oil and gas industry", Journal of Industrial Information Integration, 2020, vol. 19. DOI: https://doi.org/10.1016/j.jii.2020.100160

[7] T.A. Gileva, "Digital maturity of an enterprise: assessment and management methods" [Cifrovaya zrelost' predpriyatiya: metody ocenki i upravleniya], Science, education, economics. Economics, 2019, vol. 1(27), pp. 38-52. (In Russ.)

[8] A.I. Ageev, E.A. Asanova, O.V. Glibenko, M.V. Remizov, and V.A Smirnova, Ready for digital?Assessment of the adaptability of the hightech complex of Russia to the realities of the digital economy [ $\mathrm{K}$ cifre gotov? Ocenka adaptivnosti vysokotekhnologichnogo kompleksa Rossii $\mathrm{k}$ realiyam cifrovoj ekonomiki], Moscow: INES, 2018. (In Russ.).

[9] V. Ryzhkov, Digital transformation in Russia.Analytical report based on the results of a survey of Russian companies [Cifrovaya transformaciya v Rossii. Analiticheskij otchet na osnove rezul'tatov oprosa rossijskih kompanij], 2018. (In Russ.). Retrieved from http://www.interface.ru/iarticle/files/39873_50679725.pdf

[10] V. Ryzhkov, Digital transformation in Russia [Cifrovaya transformaciya v Rossii], 2020. (In Russ.). Retrieved from https://komandaa.pro/projects/dtr_2020

[11] Digital technologies in Russian companies [Cifrovye tekhnologii $\mathrm{v}$ rossijskih kompaniyah], 2019. (In Russ.). Retrieved from https://assets.kpmg/content/dam/kpmg/ru/pdf/2019/01/ru-ru-digitaltechnologies-in-russian-companies.pdf

[12] The Digital Advantage:How Digital Leaders Outperform Their Peers in Every Industry. Capgemini Consulting, MIT Sloan Management. Retrieved from https://www.capgemini.com/wpcontent/uploads/2017/07/the_digital_advantage_how_digital_leaders_o utperform_their_peers_in_every_industry.pdf

[13] Digital Maturity Model.Achieving Digital Maturity to Drive Grow.Available. Retrieved from https://www2.deloitte.com/content/dam/Deloitte/global/Documents/Tec hnology-Media-Telecommunications/deloitte-digital-maturity-model.pdf

[14] Digital Transformation - How to Become Digital Leader.Study, 2015. Retrieved from https://www.adlittle.com/sites/default/files/viewpoints/ADL_HowtoBec omeDigitalLeader_02.pdf

[15] L.P. Tretyak, "Mechanical engineering: development trends and international comparisons" [Mashinostroenie: tendencii razvitiya i mezhdunarodnye sopostavleniya], Studies:Institute for Economic Forecasting RAS, 2016, vol. 14, pp. 423-432. (In Russ.).

[16] I.S. Lola, and M.B. Bakeev, "Digital transformation in the manufacturing industries of Russia: results of market surveys" [Cifrovaya transformaciya $\mathrm{v}$ otraslyah obrabatyvayushchej promyshlennosti Rossii: rezultaty kon yunkturnyh obsledovanij], Bulletin of St. Petersburg University. Economics, 2019, vol. 35(4), pp. 628-657. (In Russ.)

[17] Biryusa JSC. (In Russ.). Retrieved from https://www.biryusa.ru

[18] Biryusa JSC. TAdviser. Company: Biryusa 2C Krasnoyarsk Refrigerator Plant. (In Russ.). Retrieved from http://www.tadviser.ru/index.php

[19] CJSC "Stinol". (In Russ.). Retrieved from https://mystinol.ru

[20] LG Electronics. TAdviser.Company: LG Electronics. (In Russ.). Retrieved from http://www.tadviser.ru/index.php

[21] LG Electronics in Russia. (In Russ.). Retrieved from https://www.lg.com/ru

[22] LLC BSH Household Appliances. IT passport.TAdviser. Company: BSH Household Appliances 28BSH Bosch and Siemens Home Appliances Group. (In Russ.). Retrieved from http://www.tadviser.ru/index.php

[23] Indesit. (In Russ.). Retrieved from https://www.indesit.ru

[24] Indesit.TAdviser. (In Russ.). Retrieved from http://www.tadviser.ru/index.php

[25] Household Refrigerator Plant "DON". (In Russ.). Retrieved from http://don-frost.ru 